\title{
Characterization Study of Crude Oil Degrading Microbiology Isolated from Incheon Bay
}

\author{
Hye Jin Choi ${ }^{1,2}$, Bo Young Oh${ }^{1}$, Young Sun $\mathrm{Han}^{1}$, Myung Je Hur ${ }^{1}$ and Jong-Guk Kim² \\ ${ }^{1}$ Incheon Research Institute of Public Health and Environment, Incheon 400-101, Korea \\ ${ }^{2}$ Department of Life Sciences and Biotechnology, Kyungpook National University, Daegu 702-701, Korea
}

Received December 12, 2013 /Revised June 19, 2014 /Accepted June 25, 2014

\begin{abstract}
Indigenous microorganisms play decisive roles in biodegradation. In this study, eighty strains of hydrocarbon-degrading microbes were isolated from Incheon Bay. Among them, 12 strains were selected by an oil film collapsing method. The bacterial strain 'Incheon9' was eventually selected based on its relatively higher lipase and emulsification activities, and was identified as Acinetobacter sp. (NCBI accession code: KF54854). The optimum condition for the growth and emulsification activity of Acinetobacter sp. Incheon 9 was $20^{\circ} \mathrm{C}, \mathrm{pH} 7$, and $1 \% \mathrm{NaCl}$. The optimum time for the best production of biosurfactant was $72 \mathrm{hrs}$. The oil degradation ability of Acinetobacter sp. Incheon 9 was investigated by measuring the residual oils in the culture medium by gas chromatography (FID). This research provides foundational data for eco-friendly environmental remediation by microorganisms.
\end{abstract}

Key words : Acinetobacter sp., bioemulsifier, biosurfactant, lipase, oil-degradation

\section{서 론}

한 해 1300 만 톤의 원유가 선박 등의 이동수단에 의해 지속 적으로 바다로 유출되고 있으며, 유조선 사고 등의 일시적인 원인으로 다량의 원유가 바다를 오염시키고 있다[1]. 유출된 소량의 원유는 자연 분해되기도 하지만 일시에 다량의 원유가 유출되게 되면 오일펜스를 전장하여 유출유를 포획하고 유흡 착재를 이용하여 기름을 회수하는 물리적인 방법이 우선 시행 된다. 동시에 유처리제를 살포하여 잔여 유류를 분산처리하는 화학적 방법 이용되고 있으나 이러한 방법들은 지속적인 효과 를 내기 어려울 뿐만 아니라 추후 유처리제에 의한 2차 독성을 유발하여 생태계의 자정능력을 저하시킨다. 이에 최근에는 미 생물을 이용한 친환경방법인 생물정화기법(bioremediation) 이 선호되고 있다. 이 방법은 환경정화능력이 있는 미생물을 오염된 환경에 투입하거나 토착 미생물의 생존이 최적화 되도 록 생태계의 환경을 변화시키는 것으로 주로 부유 퇴적물의 오염도가 높은 곳, 습지나 갯벌 지역, 생물 자원이 풍부한 지역 등에 권장되고 있다[11, 13, 15]. 실제 Exxon Valdez호의 유류 유출 사고 시 알라스카 해안을 오염시킨 원유를 Pseudomonas aeruginosa를 이용하여 일부 제거하였으며 현재에도 Acineto-

\footnotetext{
*Corresponding author

Tel : +82-53-950-5379, Fax : +82-53-955-5379

E-mail : kimjg@knu.ac.kr

This is an Open-Access article distributed under the terms of the Creative Commons Attribution Non-Commercial License (http://creativecommons.org/licenses/by-nc/3.0) which permits unrestricted non-commercial use, distribution, and reproduction in any medium, provided the original work is properly cited
}

bacter, Norcadia, Micrococcus, Bacillus속 등 원유 분해 미생물을 분리하여 환경에 적용하고자 하는 연구가 이뤄지고 있다[2, 9, 10].

원유 분해 미생물은 원유를 에너지원으로 이용하는 과정에 서 기질을 생분해하며 생물계면활성제를 생산한다. 생물계면 활성제(biosurfactant)는 양친매성(amphiphilicity)을 가지며 원유를 유화시켜 다른 종류의 생물들이 에너지원으로 이용하 기 용이하도록 만들어준다. 미생물이 생산하는 생물계면활성 제는 화학적 물질보다 독성이 낮고 환경에 적응하기 위해 다 양한 구조를 가지고 있으며 발효에 의한 대량생산이 가능하여 선호되고 있다. 그 중에서도 갯벌과 해안에 서식하는 미생물 이 생성하는 물질은 지구환경의 생화학적 순환에서 중요한 역할을 하는 것으로 알려져 있으며 빈영양성, 내염성 등의 특징을 가지며, 특히 저온에서도 안정적인 활성을 가져서 다 양한 분야에서 활용도가 높다 $[5,6]$.

갯벌은 조수간만의 차이에 의해 육지가 되는 지역으로 심해 퇴적물, 습지 등과 다른 독특한 생태학적 특징을 가지며 육지 와 해양의 경계지점으로 지리적 특이한 구조를 이루고 있어 오염물질의 영향을 많이 받으며 오염된 이후 회복하는데 장시 간이 필요하다[4]. 또한 갯벌은 예전부터 새우잡이, 꽃게잡이 어선들에 의해 꾸준히 항구로 활용되어 해양 오염의 가능성이 상존해왔다. 최근 선박의 대형화와 물류량의 증가로 그 위험 성이 높아지고 있는 인천 연안의 갯벌에서 원유를 탄소원과 에너지원으로 사용 할 수 있는 미생물을 분리하였다. 이들 미 생물을 대상으로 원유를 분해할 수 있는 리파아제(lipase)의 활성과 계면활성을 시킬 수 있는 유화활성(emulsification activity)을 측정하여 추후 환경정화에 사용 될 생물학적 자원을 확보하고자 하였다. 


\section{재료 및 방법}

\section{시료 채취 및 원유 분해 미생물 선별}

시료는 인천 연안의 동막(latitude: $37^{\circ} 35^{\prime} 27.90^{\prime \prime}, 37^{\circ} 35^{\prime} 18.18^{\prime \prime}$, $37^{\circ} 35^{\prime} 03.65^{\prime \prime}$, longitude: $126^{\circ} 27^{\prime} 26.80^{\prime \prime}, 126^{\circ} 27^{\prime} 20.61^{\prime \prime}, 126^{\circ} 27^{\prime}$ 11.36), 북항 (latitude: $37^{\circ} 29^{\prime} 28.07^{\prime \prime}, 37^{\circ} 29^{\prime} 29.40^{\prime \prime}, 37^{\circ} 29^{\prime} 44.40^{\prime \prime}$, longitude: $\left.126^{\circ} 37^{\prime} 10.58^{\prime \prime}, 126^{\circ} 37^{\prime} 10.10^{\prime \prime}, 126^{\circ} 38^{\prime} 18.30^{\prime \prime}\right)$, 아라뱃 길(latitude:37 $32^{\prime} 37.10^{\prime \prime}, 37^{\circ} 32^{\prime} 38.50^{\prime \prime}, 37^{\circ} 32^{\prime} 39.60^{\prime \prime}$, longitude: $\left.126^{\circ} 34^{\prime} 22.20^{\prime \prime}, 126^{\circ} 34^{\prime} 26.20^{\prime \prime}, 126^{\circ} 34^{\prime} 29.70^{\prime \prime}\right)$ 에서 채취하였으며 각 지역 당 3 지점의 갯벌을 표면에서 $10 \mathrm{~cm}$ 깊이에서 멸균 도구를 이용하여 채취하고 아이스 팩에 담아 이동하였다.

미생물의 분리를 위해 $0.05 \% \mathrm{~K}_{2} \mathrm{HPO}_{4}, 0.1 \% \mathrm{NH}_{4} \mathrm{Cl}, 0.2 \%$ $\mathrm{Na}_{2} \mathrm{SO}_{4}, 0.0001 \% \mathrm{CaCl}_{2} * 6 \mathrm{H}_{2} \mathrm{O}, 0.1 \% \mathrm{MgSO}_{4} * 7 \mathrm{H}_{2} \mathrm{O}, 0.0001 \%$ $\mathrm{FeSO}_{4}$ 에 $1 \%$ crude oil를 첨가하여 원유를 유일 탄소원으로 하는 최소배지를 이용하였다. 갯벌 $5 \mathrm{~g}$ 을 $0.85 \%$ 생리식염수 $45 \mathrm{ml}$ 에 희석하여 최소배지에 도말 한 후 다양한 모양의 집락 을 순수분리하여 $20^{\circ} \mathrm{C}$ 에서 14 일간 배양하였다. 증류수 $5 \mathrm{ml}$ 에 원유 $20 \mu \mathrm{l}$ 를 떨어뜨려 oil film을 형성한 뒤 분리된 균주의 배양액 $5 \mu \mathrm{l}$ 를 oil film 중앙에 떨어뜨려 형성된 clear zone의 지름으로 oil film collapsing 활성 정도를 측정하여 원유 분해 능이 있는 미생물을 1차 선별하였다[8]. 선택 된 균주는 $20 \%$ glycerol 첨가 Brain Heart Infusion (Difco, USA)배지에 현탁 하여 $-70^{\circ} \mathrm{C}$ 에 보관하면서 실험하였다.

\section{균주 동정 및 생화학특성 분석}

원유를 유일 탄소원으로 하는 배지에서 7 일간 $\left(20^{\circ} \mathrm{C}\right)$ 선택된 균주들을 배양하여 total genomic DNA (G-spin DNA extraction kit, INTRON Biotech, Korea)를 추출하였다. 유전자 를 통한 종(species)분석을 위해 $16 \mathrm{~s}$ rRNA 유전자를 증폭하였 으며 이때 bacterial universal primer 27F (5'-AGAGTTTGATCCTGGCTCAG-3')와 1492R (5'-GGTTACCTTGTTACGA-
CTT-3 $)$ 를 이용하였다. Primer $(10 \mathrm{pmol})$ 를 각각 $5 \mu \mathrm{l}$, 주형 DNA $5 \mu l$, PCR premix $10 \mu \mathrm{l}$ (Intron, Korea)을 혼합물로 하여 핵산증폭기(2720 thermal cycle, $\mathrm{AB}, \mathrm{USA})$ 를 이용하여 증폭하 였다. 조건은 $94^{\circ} \mathrm{C}$ 에서 10 분간 반응 후 $94^{\circ} \mathrm{C}$ 에서 1 분, $54^{\circ} \mathrm{C}$ 에 서 45 초, $72^{\circ} \mathrm{C}$ 에서 45 초로 35 회 반복 반응하고, $72^{\circ} \mathrm{C}$ 에서 10 분 간 추가반응 시켰다. 증폭된 유전자를 정제(Labo-gel extraction kit, Cosmo_geneteck, Korea)하여 pGEM-T vector (Promega, USA)에 ligation시킨 후 One shot Top 10-chemically competent cell (Invitrogen, USA)에 transformation시켜 X-gal과 IPTG가 첨가된 Luria-Bertani (Difco, USA)배지에서 형질전환 된 colony를 선택하고 플라스미드를 추출(plasmid-purification kit, cosmo_geneteck, Korea)하였 으며 Cosmo genetech (Korea)에 의뢰하여 염기서열을 분석하 였다. BLAST (Basic Local Alignment Search Tool) search를 이용하여 NCBI (National Center for Biotechnology Information)의 genbank의 유전자 데이타와 비교 분석하였으 며 유전자가 유사한 균주들과 염기서열 유사도를 확인하기 위해 Bio-Edit (ver 7.2.3.)과 Phylogenetic Tree version MEGA (ver 5.2)를 통해 phylogenetic tree를 그렸다.

\section{$\mathrm{NCBI}$ accession number}

분석한 $16 \mathrm{~s}$ rRNA 유전자를 NCBI의 Genbank 유전자 데이 터 베이스에 등록하여 accession code (KF548540)를 부여 받았 다.

\section{리파아제 활성 측정}

Bulow와 Mosbach의 방법을 변형하여 p-nitrophenyl-butyrate $10 \mu \mathrm{l}$, ethanol $40 \mu \mathrm{l}, 50 \mathrm{mM}$ tirs-buffer (pH 8.0) 950 $\mu \mathrm{l}$ 를 기질 용액으로 하여 원심분리 한 배양액 $500 \mu \mathrm{l}$ 을 넣고 $30^{\circ} \mathrm{C}$ 에서 30 분간 반응시켰다. TCA (Trichloroacetic acid)용액 $300 \mu \mathrm{l}$ 를 첨가하여 원심분리 $(9,000 \mathrm{~g}, 5$ 분 $)$ 한 후 $410 \mathrm{~nm}$ 에서

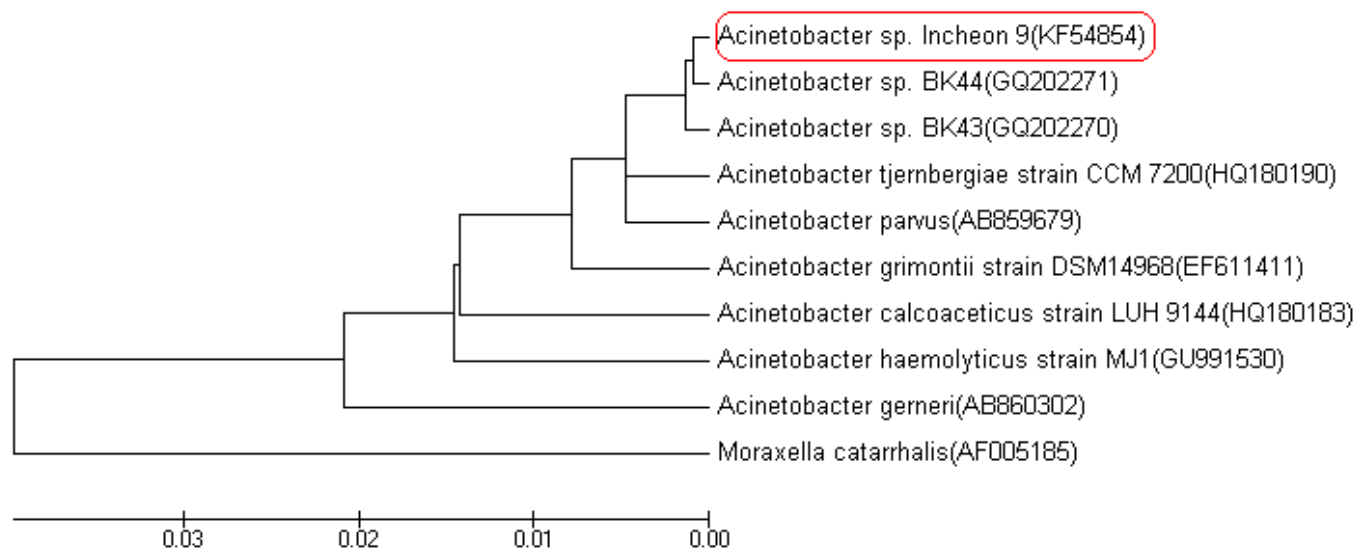

Fig. 1. Phylogenetic relationships of the Acinetobacter sp. Incheon9 related bacteria based on the partial 16s rRNA gene sequence. The phylogenetic tree was generated by the neighbor-joining method. Bootstrap value, expressed as percentages of 10,000 replication, are given at major branching points. 
흡광도(Infinite M200 Pro, Tecan, $540 \mathrm{~nm}$ )를 측정하여 리파아 제 활성을 측정하였다. 이때 standard는 p-nitrophenol을 사용 하였다[3].

\section{유화활성 및 유화안정성 측정}

유화활성(emulsification activity)측정은 7일간 배양한 액체 배지를 원심분리 $(13,000 \mathrm{~g}, 10$ 분)한 상등액 $2 \mathrm{ml}$ 에 $0.2 \mathrm{M}$ phosphate buffer (pH 7.0) $2 \mathrm{ml}$ 를 혼합 한 후 유화기질로 n-hexanedecane $1 \mathrm{ml}$ 를 첨가하여 1 분간 강하게 교반하여 유화시킨 후 10 분간 정치시키고 하층부의 $200 \mathrm{\mu l}$ 를 유화활성을 측정 $(540$ $\mathrm{nm}$ )하였다[16]. 이때 생물계면활성제를 생산하는 Acinetobacter sp. (KACC14342)와 Pseudomonas aeruginosa (KACC10186)를 농업진흥청의 농업자원센터에서 분양 받아 비교 균주로 사용 하였다.

\section{기질에 따른 유화활성과 유화안정성 측정}

탄화수소의 길이에 따라 여러 종류의 탄화수소를 기질로 하여 균주의 유화활성을 측정하였다. 유화안정성은 유화활성 측정 시와 동일한 방법으로 실험하고 실온에서 방치하면서 매 10 분마다 총 60 분간 흡광도를 측정하였으며 그 값을 $\log$ 값 으로 환산하여 나타냈고 이 값들간의 기울기를 유화활성의 안정도 상수 $\mathrm{Kd}($ 시간당 붕괴되는 유화활성의 기울기 값)로 나타내었다.

\section{최적 배양 및 유화활성 조건}

균주의 최적 성장 조건 조사를 위해 균주를 McFarland 3.0 으로 탁도로 맞추고 LB broth (Difco, USA)에 1\% 해당량의 균주를 접종하였다. $20^{\circ} \mathrm{C}, 30^{\circ} \mathrm{C}, 37^{\circ} \mathrm{C}, 42^{\circ} \mathrm{C}$ 에서 배양하면서 온 도별 성장속도를 측정하였고, $1 \mathrm{~N} \mathrm{HCl}$ 과 $1 \mathrm{~N} \mathrm{NaOH}$ 를 이용하 여 $\mathrm{pH} 5, \mathrm{pH} 7, \mathrm{pH} 8, \mathrm{pH}$ 9로 만든 $\mathrm{LB}$ 배지에 각각 균주를 접종 후 $20^{\circ} \mathrm{C}$ 에서 72 시간 동안 배양하면서 염의 농도가 균주 의 생장에 미치는 영향을 측정하였다. 배지에 $\mathrm{NaCl}$ 을 첨가하 여 0 5\%의 염에 따른 성장도를 측정하였다. 또 시간별 균주의 성장속도를 측정하기 위해 $1 \% \mathrm{NaCl}$ 을 첨가 한 $\mathrm{LB}$ broth $(\mathrm{pH}$ 7)에 균을 접종하고 $20^{\circ} \mathrm{C}$ 에서 배양하면서 $600 \mathrm{~nm}$ 에서 성장도 (Infinite M200 Pro, Tecan)를 측정하였다. 그리고 각각의 다른 조건의 배양액을 원심분리하여 상등액을 시험용액으로하여 유화활성 실험을 시행하였으며 이를 통해 배양조건에 따른 유화활성을 측정하였다.

\section{Gas chromatography분석}

유일한 탄소원 및 에너지원으로서 crude oil을 공급하여 배 양한 미생물에 의해 분해되고 남은 잔류 원유량을 추출하여 분석하였다. 잔류 원유를 추출하기 위해 균주 배양액 $50 \mathrm{ml}$ 에 $1 \%$ crude oil를 첨가하여 7일 배양하였다. 이 배양액에 $\mathrm{HCl}$ $2 \mathrm{ml}$ 를 첨가하여 반응을 멈춘 후 추출 용매로 hexane $25 \mathrm{ml}$ 를
이용하여 3회 반복 추출하였다. $\mathrm{Na}_{2} \mathrm{SO}_{4}$ 를 이용하여 수분을 제거한 후 질소가스로 hexane잔류물을 제거하고 잔류 원유를 농축하였다. 농축된 시료를 hexane $2 \mathrm{ml}$ 에 녹여 gas chromatography (Agilent technologies, USA)분석하였다. 이때 FID (Flame Ionization Detector) 검출기와 HP5 column (30 $\mathrm{m} \times 0.320 \mathrm{~mm}$ I.D., $0.25 \mu \mathrm{m}$ film thickness, Agilent technologies, USA)을 이용하였으며 carrier gas로 질소를 사용하 여 $1.0 \mathrm{ml} / \mathrm{min}$ 유속으로 흘려주었다. 주입온도는 $250^{\circ} \mathrm{C}$, 측정 온도는 $250^{\circ} \mathrm{C}$, 오븐 온도는 $80^{\circ} \mathrm{C}$ 에서 $300^{\circ} \mathrm{C}$ 까지 승온 온도 1 $5{ }^{\circ} \mathrm{C} / \mathrm{min}$ 로 하여 분석하였다.

\section{결과 및 고찰}

\section{원유 분해 미생물의 분리 및 동정}

해양에는 석유탄화수소를 탄소원과 에너지원으로 사용하 는 미생물이 존재하며 이러한 미생물은 산업폐수 또는 생활하 수가 유입되는 지점에 널리 분포한다[4]. 선박의 이동이 잦으 면서 수도권과 인접하여 생활하수의 유입이 많고 정유공장 등의 지대가 인접한 인천연안의 갯벌에서 원유(crude oil)를 탄소원으로 하는 80 균주를 순수분리 하고 이들 균주에 대해 oil film-collapsing assay법을 이용하여 생물계면활성을 보유 하여 원유를 유화시킬 수 있는 12 균주를 2 차 선별하였다.

이들 중 활성이 좋았던 Incheon9의 $16 \mathrm{~s}$ rRNA유전자를 분 석한 결과 Acinetobacter sp. 종과 유전자가 유사하였고 이들 균주들과 유전적 상관성을 알아본 결과 Acinetobater sp. BK44 (GQ202271)와 유전적 연관도가 $99 \%$ 로 상동성이 높았다. 이에 Acinetobater sp. Incheon9라 명명하고 NCBI에 유전자 염기서 열을 등록하여 accession code KF548540을 부여 받았다(Fig. $1)$.

\section{리파아제 활성}

리파아제는 triacylglycerol을 분해하여 저분자로 만드는 효 소로 물과 기질의 계면에서 기질을 용해하는 계면활성현상 (interfacial activation)을 가진다[17]. 이러한 리파아제의 성질 을 이용하여 세제산업에서는 Humicolar lanuginose를, 유화제 산업에서는 Chromobacterium viscosum균주를 이용하고 있다 [5]. 이외에도 환경분야에서 기름으로 오염된 토양이나 모래, 유공장의 폐수처리를 위해 미생물의 리파아제를 이용하고 하 는 연구가 진행되고 있다 [7, 18]. p-nitrophenyl-butyrate를 기 질로 하여 분리된 균주들의 lipase의 활성을 측정한 결과 Incheon9가 $28.32 \mathrm{unit} / \mathrm{ml}$ 로 가장 활성이 좋았다. 이는 Acinetobacter sp. KACC14342의 $16.82 \mathrm{unit} / \mathrm{ml}$, Pseudomonas aeruginosa KACC10186의 $24.53 \mathrm{unit} / \mathrm{ml}$ 보다 활성이 좋은 것으로 측정되었다(Table 1, A). 
Table 1. Emulsification activity and lipase activity of Acinetobacter sp. KACC 14342, Psudomonas aeroginosa KACC 101806 and Acinetobacter sp. Incehon 9

\begin{tabular}{lcc}
\hline \multicolumn{1}{c}{ Bacterial strain } & A) Lipase activity & B) Emulsification activity \\
\hline Acinetobacter sp. KACC 14342 & 16.82 & 0.14 \\
Psudomonas aeroginosa KACC 101806 & 24.53 & 0.06 \\
Acinetobacter sp. Incehon 9 & 28.32 & 0.38 \\
\hline
\end{tabular}

A) Lipase activity B) Emulsification activity

\section{유화활성 측정}

생물계면활성제를 생산하는 미생물들은 n-alkane의 탄소 를 이용하며 이 과정에서 고분자의 탄화수소 화합물이 미세한 입자로 유화되고 세포와 기질의 접촉면이 넓어진다. 이러한 작용에 의해 고분자 물질이 보다 쉽게 분해 할 수 있으며 추후 유류 유출에 의한 해양 오염에도 응용 될 수 있다[6,12]. 이에 고분자물질인 $\mathrm{n}$-hexanedecane $(\mathrm{C} 16)$ 을 분해하는 정도로 생물 유화활성도를 측정한 결과 Incheon9는 0.38 (OD $540 \mathrm{~nm}$ )로 활성이 가장 좋았다. 이는 생물계면활성제를 생산한다고 알려 진 Acinetobacter sp. KACC14342의 0.14, Pseudomonas aeruginosa KACC10186의 0.06보다 활성이 좋은 것으로 측정되었다 (Table 1, B). 기존 연구에 의하면 Candida rugosa와 Pseudomonas aeruginos가 생성하는 리파아제는 계면활성능력 이 없으며 Proteus vulgaris가 생성하는 리파아제는 부분적으로 계면활성을 가진다고 알려져 있다[7]. 그러나 Incheon9의 경우 리파아제 활성도 가지면서 동시에 계면활성도 가지는 것으로 사료된다.

\section{기질에 따른 유화활성과 유화안정성 측정}

탄소원의 길이에 따른 여러 종류의 탄화수소화합물을 기질 로 하여 기질별 유화활성을 측정하였고, 또 시간에 따라 유화 활성이 줄어드는 정도를 측정하여 유화안정성을 측정하였다.

탄소원에 따른 기질별로 유화활성은 olive oil을 분해할 때 유화능이 1.63으로 가장 좋았으며 hexane (C6)은 0.33, octane (C8)은 0.27, decane (C10)은 0.28, tetradecane (C14)은 0.31,

Table 2. Emulsification activity and stabilization of various substrate by biosurfactant solution

\begin{tabular}{lcc}
\hline \multicolumn{1}{c}{ Substrate } & $\begin{array}{c}\text { A) Emulsification } \\
\text { activity } \\
\text { (OD } 540 \mathrm{~nm})\end{array}$ & $\begin{array}{c}\text { B) } \\
\text { Decay constant } \\
(\mathrm{Kd}, 10-2)\end{array}$ \\
\hline Olive oil & 1.63 & -3.0 \\
Triacetin (C2:0) & 0.69 & -3.2 \\
Tributyrin (C4:0) & 1.49 & -2.3 \\
Hexane (C6) & 0.33 & -5.6 \\
Octane (C8) & 0.27 & -4.2 \\
Decane (C10) & 0.28 & -5.2 \\
Tetradecane (C14) & 0.31 & -1.2 \\
Hexadecane (C16) & 0.38 & -0.3 \\
\hline
\end{tabular}

A) Emulsification activity B) Decay constant, $\mathrm{Kd}$ hexadecane (C16)은 0.38로 $\mathrm{C6}$ C18은 기질별 유화활성이 비 슷하였다(Table 2, A). Acinetobacter sp. BE-254와 Nocardia sp. L-417가 비교적 긴 탄소화합물인 n-tetradecane, n-hexadecane에서 유화활성이 좋았던 기존의 연구와 달리 Incheon 9는 탄화수소수가 적은 tributyrin에서 유화활성이 높게 측정 되었다[16].

유화안정도는 기질에 대한 유화안정화 정도를 나타내는 값 으로 시간의 지남에 따라 유화정도가 붕괴되는 정도를 기울기 $(\mathrm{Kd}$, decay constant)로 나타내며 $\mathrm{Kd}$ 값과 유화안정도는 반비 례 관계이다. 대부분의 기질에 대해 Acinetobacter sp. Incheon9 는 대부분의 탄화수소기질에 대해 음의 $\mathrm{Kd}$ 값을 가져서 안정 적인 유화활성을 보였다(Table 2, B).

\section{최적 배양 및 유화활성 조건}

Acinetobacter sp. Incheon9의 성장 조건별 유화활성을 측정 한 결과 서로 상관성이 있었다. 온도의 영향은 $20^{\circ} \mathrm{C}$ 가 성장과 유화활성의 최적의 온도였으며 $30^{\circ} \mathrm{C}, 37^{\circ} \mathrm{C}, 42^{\circ} \mathrm{C}$ 에서는 유화 활성뿐 아니라 성장도 감소하였다(Fig 2, A). 이는 기존에 보고 된 Acinetobacter sp. 2-3A의 최적 온도 $25 \sim 30^{\circ} \mathrm{C}$, Acinetobacter $\mathrm{sp} . \mathrm{BE}-254$ 의 $30^{\circ} \mathrm{C}$ 보다 낮은 온도에서 활성도가 좋은 것으로 측정되었다[16]. 우리나라 해양의 연평균 수온이 $15.8^{\circ} \mathrm{C}$, 토양 은 $25^{\circ} \mathrm{C}$ 로 Incheon9는 토양뿐 아니라 해양에서도 활성을 유지 할 것으로 사료된다[14].

또, 배지의 초기 $\mathrm{pH}$ 에 따른 성장과 유화활성의 영향을 조사 한 결과 $\mathrm{pH}$ 7이 가장 최적인 것으로 측정되는데, 이는 Acinetobactersp. 2-3A가 pH 7에서 활성이 좋았던 기존 연구와 유사한 결과였다(Fig. 2, B).

$\mathrm{NaCl}$ 농도에 따른 성장과 유화활성을 조사한 결과 $0 ~ 1 \%$ 의 $\mathrm{NaCl}$ 첨가 배지로 배양 결과 활성이 높게 나타났으며 $\mathrm{NaCl}$ 이 $0 \%$ 일 때 보다 $1 \%$ 에서 유화능과 성장도가 좋았다(Fig. 2, C). Incheon9는 낮은 염분에서 활성이 좋은 것으로 측정되어 해수 와 담수가 섞이는 하구지역에서 활용도가 높을 것으로 사료된 다.

Acinetobacter sp. Incheon9의 성장과 유화활성과의 상관관 계를 알아보기 위해 배양시간에 따른 생물계면활성제의 유화 활성을 측정한 결과 균체의 성장과 함께 유화능도 증가하고 대수증식기에서 정지기가 되는 72시간에서 96시간까지가 최 고의 활성도를 보였다(Fig. 3). 이는 대수증식기까지 균의 증식 

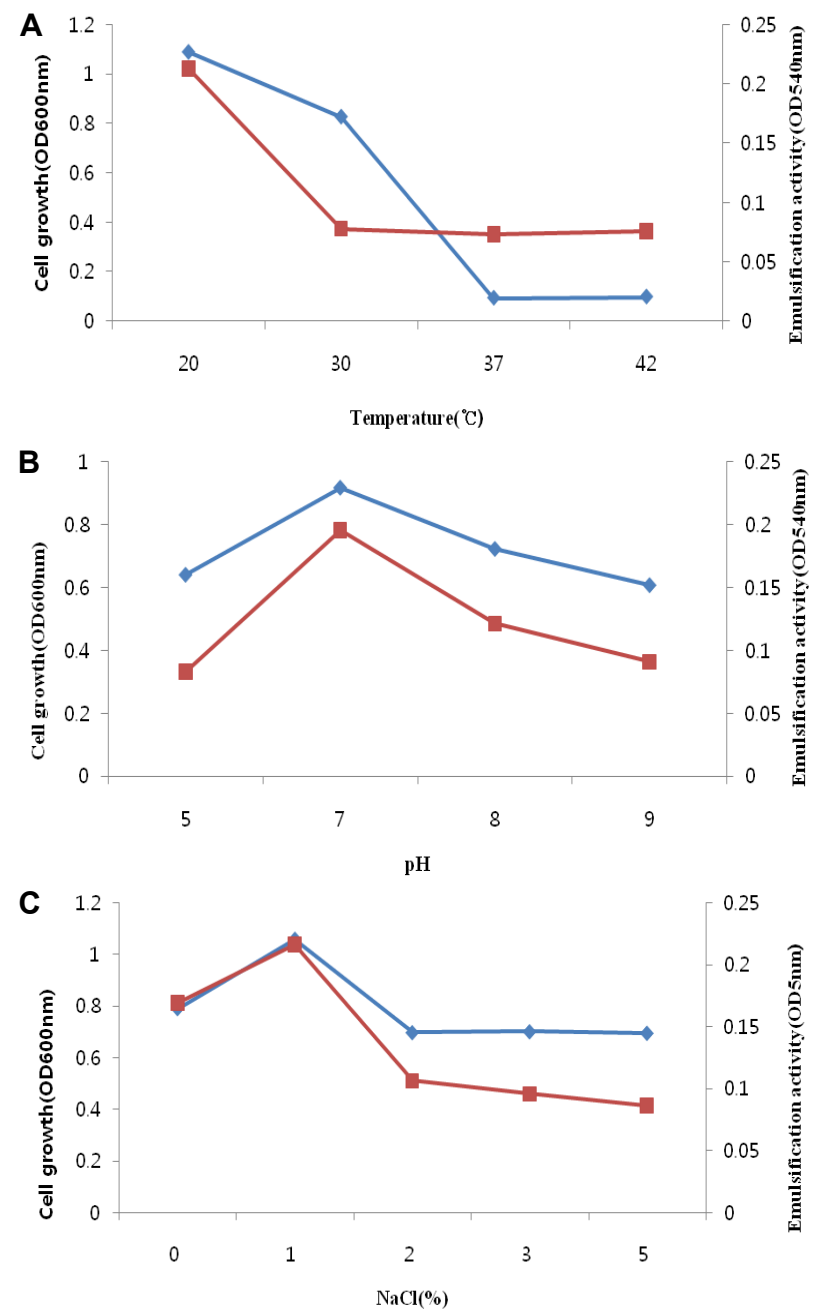

Fig. 2. Effects of temperature, $\mathrm{pH}$ and $\mathrm{NaCl}$ concentration of the growth and emulsification activity of Acinetobacter sp. Incheon9. A) Temperature : $20^{\circ} \mathrm{C}, 30^{\circ} \mathrm{C}, 37^{\circ} \mathrm{C}$ and 4 $2^{\circ} \mathrm{C}$ for $72 \mathrm{hr} \quad$ B) $\mathrm{pH}$ : $\mathrm{pH} 5, \mathrm{pH} 7, \mathrm{pH} 8, \mathrm{pH} 9$ at $20^{\circ} \mathrm{C}$ for $72 \mathrm{hr} \mathrm{C}$ ) $\mathrm{NaCl}: 0 \%, 1 \%, 2 \%, 3 \%, 5 \%$ ( : Emulsification activity, : Cell growth).

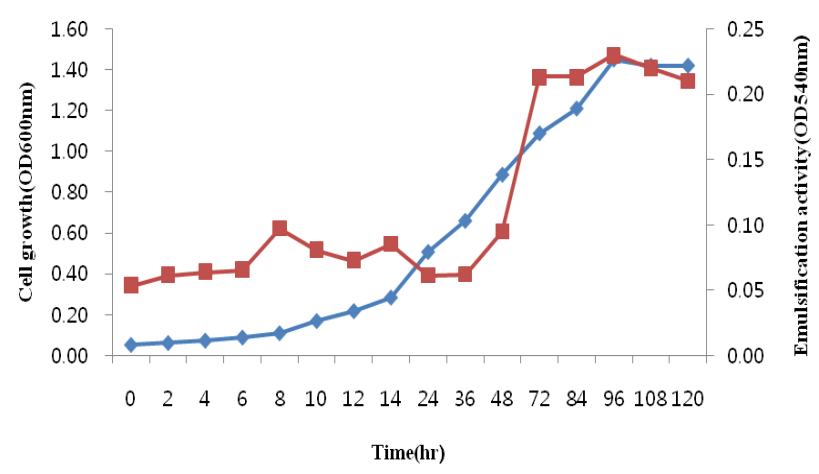

Fig. 3. Time course growth and biosurfactant production by Acetinobacter sp. Incheon9. The cell was cultured in LB medium $30^{\circ} \mathrm{C}$, pH 7 added $1 \% \mathrm{NaCl}$ for $72 \mathrm{hr}$. Emulsification activity, $\diamond$ : Cell growth)).
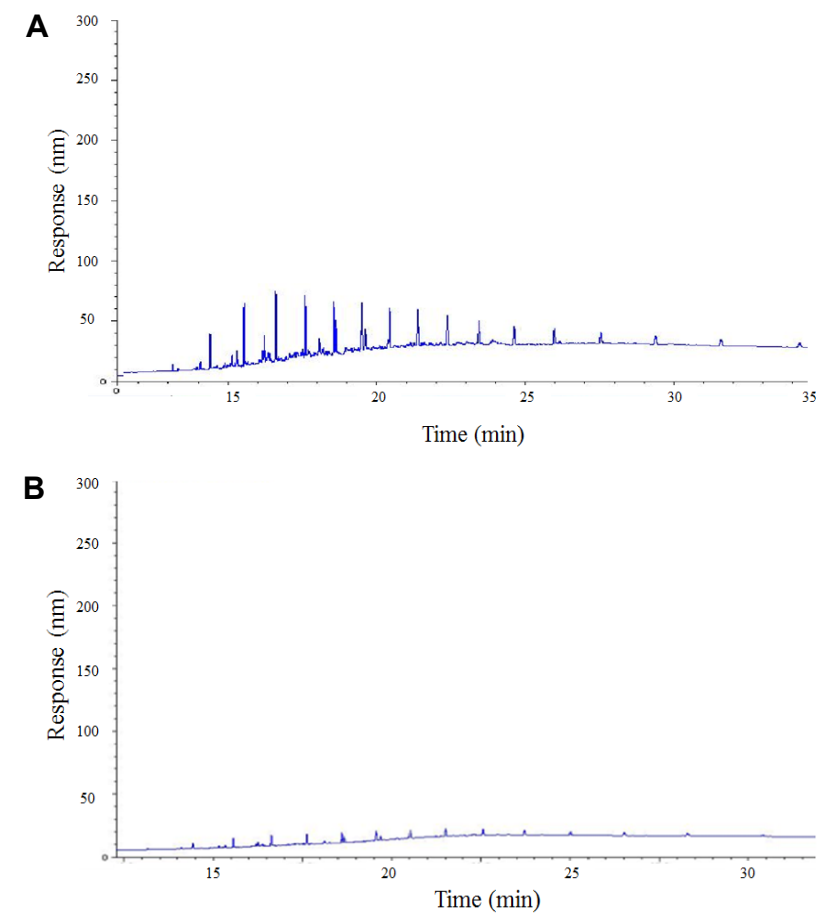

Fig. 4. Gas chromatograms of total hydrocarbon fractions form the undegraded substrate oil, crude oil. A) sterile control B) treated with Acinetobacter sp. Incheon9.

과 더불어 생물계면활성제의 활성이 증가하다가 정지기에 들 어가면서 증가량이 감소한다는 기존 보고와 유사하였다[10].

\section{원유 분해 활성 확인}

원유에는 saturates $(61 \%)$, aromatics (335), resin (4\%), asphaltenes $(2 \%)$ 등이 함유 되어 있으며 이들 원유 성분 중 paraffine계 탄화수소인 saturates의 분해정도를 gas chromatography로 분석하였다. Incheon9를 접종한 배양액과 무처리군 배양액을 동일한 환경에서 7일간 배양한 결과 carbon chain이 대부분 분해되었음을 정성적으로 확인하였다(Fig. 4).

인천연안 갯벌에서 원유를 유일 탄소원으로 하여 성장 할 수 있는 균주를 분리하였으며 $16 \mathrm{~s} \mathrm{rRNA}$ 유전자 분석을 통해 Acinetobacter sp. Incheon9이라 명명하고 NCBI에 등록 (KF548540)하였다. 이 균주는 생물계면활성능력과 리파아제 활성을 동시에 가지며 Paraffine계 탄화수소를 분해함을 확인 하였다. 그리고 $20^{\circ} \mathrm{C}, \mathrm{pH} \mathrm{7,1 \%} \mathrm{NaCl}$ 첨가한 배지에서 배양 시 최적 성장 및 유화활성을 보였으며 72시간에서 96시간까지 의 대수증식기에 가장 활발한 유화활성능력을 가지는 것으로 측정되었다. 이번 연구는 환경정화에 활용 가능한 생물자원 찾은 연구로 실제 활용을 위해서는 실제 환경에도 실험실과 유사한 활성을 가지는지에 대한 연구 등이 추가 되어 할 것으 로 사료된다. 


\section{References}

1. Atlas, R. M. 1981. Microbial degradation of petroleum hydrocarbon an environmental perspective. Microbiol Rev 45, 180-239.

2. Bragg, J. R., Prince, R. C., Harner, E. J. and Atlas, R. M. 1994. Effectiveness of bioremediation for the Exxon Valdez oil spill. Nature $368,413-418$.

3. Bulow, L. and Mosbach, K. 1987. The expression in E.coli of a polymeric gene coding for and esterase mimic catalyzing the hydrolysis of p-nitrophenyl esters. FEBS Lett 210, 147-152.

4. Carling, P. A. 1982. Temporal and spatial variation in inter tidal sedimentation rates. Sedimentology 29, 17-23.

5. Choo, W. W., Kurihara, T., Suzui, T., Soda, K. and Esaki, N. 1998. A cold adapted lipase of an Alaskan psychrotroph Pseudomona sp. strain B11-1: gene cloning and enzyme purification and characterization. Appl Envrion Microbiol 64, 486-491.

6. Gtutnick, D. L. and Rosenberg, E. 1977. Oil tankers and pollution: a microbiological approach. Annu Rev Microbiol 31, 379-196.

7. Hemila, H., Koivula, T. T. and Palva, I. 1994. Hormone sensitive lipase is closely related to several bacterial proteins, and distantly related to acetyl cholinesterase and lipoprotein lipase: Identification of a super family of esterase and lipase. Biochim Biophys Acta 1210, 249-253.

8. Jain, D. K., Collins, T. D. L., Lee, H. and Trevors, J. T. 1991. A drop collapsing test for screening surfactant producing microorganism. J Mirobiol Methods 13, 271-279.

9. Kim, H. S., Lee, C. H. and Suh, H. H. 1997. A lipopeptide biosurfactant produced by Bacillus subtilis C9 selected through the oil film-collapsing assay. J Microbiol Biotechnol 7, 180-188

10. Kim, H. J., kim, B. J., Ha, S. D., Hwang, S. H. and Kong, J. Y. 1999. Biodegradation of crude oil by marine bacterium Pseudomonas sp. CHCS-2 and composition of the biosurfactant. KSBB J 14, 192-197.

11. Margesin, R. and Schinner, F. 2001. Biodegradation and bioremediation of hydrocarbons in extreme environments. Appl Microbiol Biotechnol 56, 650-663.

12. Park, J. Y., Park, I, S., Suh, K. H. and Hong, Y. K. 1998. Emulsification of bunker-C oil by a marine bacterium Achromobacter sp. M-1220. Korean J Appl Microbiol Bioeng 16, 384-388.

13. Prince, R. C. 1993. Petroleum spill bioremediation in marine environments. Crit Rev Microbiol 19, 217-242.

14. Shim, S. H. and Park, K. R. 2006. Characteristics of Biosurfactant producing Pseudomonas sp. G314. Korean J Micobiol 42, 286-293.

15. Swannell, R. P., Lee, J. K. and McDona, M. 1996. Field Evaluation of marine oil spill bioremediation. Microbiol ReV 60, 342-365.

16. Takeshi, S., Toru, N., Tatsou, K., Tokuzo, N. and Nobuyoshi, E. 2001. Cold-active lipolytic activity of psychtrophic Acinetobacter sp. Strain No, 6. J Biosci Bioeng 92, 144-148.

17. Van der Mei, H. C., Van der Belt-Gritter, B. and Busscher, H. J. 1995. Implication of microbial adhesion to hydrocarbons for evaluating cell surface hydrophobicity adhesion mechanism. Colloids Surf B Biointerfaces 5, 117-126.

18. Vaughan, M., Berger, J. E. and Steinberg, D. 1964. Hormonesensitive lipase and mono glyceride lipase activities in adipose tissue. J Biol Chem 239, 401-409.

\title{
초록 : 인천 연안에서 분리한 원유 분해 미생물의 특성 연구
}

\author{
최혜진 ${ }^{1,2} \cdot$ 오보영 ${ }^{1} \cdot$ 한영선 $^{1} \cdot$ 허명제 $^{1} \cdot$ 김종국 ${ }^{2 *}$ \\ ( ${ }^{1}$ 인천보건환경연구원, ${ }^{2}$ 경북대학교 생명공학부)
}

토착 미생물은 친환경적 정화에 중요한 역할을 한다. 원유(crude oil)를 분해하는 80 균주를 인천 연안에서 분리 하고 oil film collapsing방법을 이용하여 유화능이 있는 12균주를 선별하였다. 이들 균주에 대해 p-nitrophenyl butylrate를 기질로 이용하여 리파아제(lipase)활성과 n-hexanedecane을 기질로 이용하여 유화(emulsification)활 성을 측정하여 원유 분해 활성이 좋은 Incheon9를 선별하고 gas chromatography (FID)로 paraffine계 탄화수소 를 감소시키는 것을 확인하였다. 이 균주의 $16 \mathrm{~s} \mathrm{rRNA}$ 유전자 분석을 통해 Acinetobacter sp.로 동정하고 NCBI에 등록하여 accession code (KF548540)를 부여 받았다. Acinetobacter sp. Incheon9의 성장과 유화능이 최적 배양 조 건은 $20^{\circ} \mathrm{C}, \mathrm{pH} 7,1 \% \mathrm{NaCl}$ 였으며 대수증식기 기간에 가장 높은 유화능을 보였으며 탄화수소가 짧은 trybutyrin에 서 분해능력이 좋았다. 이번 연구결과는 환경오염에 활용 가능한 미생물자원군의 확보를 위한 연구였으며 추후 활용을 위해서는 실제 환경에서 동일한 활성을 가지는지 여부에 대한 연구가 추가로 진행되어야 할 것이다. 